\title{
THE IMPACT OF BREXIT ON DESIGNING A MATERIAL-BASED GLOBAL SUPPLY CHAIN NETWORK FOR ASIAN MANUFACTURERS
}

\begin{abstract}
Purpose - The purpose of this paper is to investigate effects on global supply chain reconfigured in the customs duty rate of parts and specific material types brought about by Brexit and the Trans-Pacific Partnership.

Design/methodology/approach - The supply chain network is modeled and formulated using mixed integer programming. Numerical experiments are conducted using bill of materials with information such as the procurement cost of each part, 3D-CAD and an industry census.

Findings - The experiments indicates that if the customs duty rate increases by Brexit, manufacturers would be necessary to restructure supply chain configuration and locate the domestic factory and market. Additionally, when the UK leaves the EU and joins the TPP, there is a case where the total cost decreases in the global supply chain network compared to the baseline without Brexit. Therefore, it is reasonable for the UK to join the TPP.

Practical implications - The study shows how a new trading rules from non-partnership countries can critically disrupt existing global supply chain equilibrium. Asian manufacturers should evaluate a move to more local sourcing, opening new facilities and setting up warehouses to stock finished goods or raw materials in different trading areas to overcome any barriers to the goods movement.

Originality/value - This study enables us to quantitatively evaluate what there are opportunities or cost increasing risks by the selection of supply chain configuration for Asian manufacturers by political and economic factors of each country such as Brexit and participation in TPP.
\end{abstract}

Keywords: Sustainable Supply Chain, Bill of Materials, Free Trade Agreement, Economic Partnership Agreement, Material Imported Tax, Future Production 


\section{Introduction}

Sustainability is to continue for a long time without causing damage to the environment (Pearson education, 2018) and is a source of competitive advantage and a matter of corporate survival (Mahler, 2007). Many CEOs embrace sustainability as a topline priority (Mahler, 2007). Sustainable development mainly consists of a triple bottom line including economic aspects, environmental performance and social responsibility (Eskandarpour et al., 2015), and is required for international corporate activities. The triple bottom line approach may need to be commonly adapted to the country and cultural context in focus (Santos et al., 2014). Song et al. (2018a) conducted the analysis considering the triple bottom line in these three aspects, and showed that the company's production efficiency and further increase green total factor productivity (GTFP) are improved by proper enhancement of environmental regulation intensity although company costs may increase in the short term. In an economic aspect, international manufacturers concentrate on forming sustainable global supply chain networks to survive international competition throughout reducing production and logistics costs (Hosoda et al., 2016). Additionally, in terms of environmental performance, it is also necessary to construct a supply chain network that minimizes energy consumption and pollutant emissions in order to develop sustainably for the industry (Song et al., 2018b). In these networks, which include international suppliers and factories, customs duty is imposed to international transportations of parts and products. Additionally, the customs duty rate is changed by reduction in and elimination of economic factors such as free trade agreements (FTAs) and economic partnership agreements (EPAs). An FTA aims to reduce or eliminate tariffs between specific countries or regions, while an EPA sets down rules for promoting trade between specific countries or regions (Ministry of Foreign Affairs of Japan, 2017). Manufacturers should also consider economic factors such as customs duties to reduce costs (Amin et al. 2017). For example, the preferential tariffs in the European Union (EU) customs union only apply on transportation between countries within the EU.

In recent years, "Brexit", has become an abbreviation for "British exit," a political trend concerning customs duty. Thus, social circumstances are drastically changing surrounding the sustainable supply chain. In June 2016, British citizens decided to withdraw from the EU by a referendum (BBC, 2018a). As the United Kingdom (UK) leaves the EU, the country will also leave the customs duty union of the EU, and the duty between the UK and EU countries will be revived. Currently, rules on customs duty in the UK are being discussed (HM Government, 2018). Depending on the new customs duty rate, the supply chain configuration of an international manufacturer that has factories in the UK and EU will be affected. An example of the impact of Brexit is Japanese car manufacturer Toyota, which has structured a global supply chain network including the EU and Asia. The UK factory of Toyota produces 150,000 cars per year, and $90 \%$ of those are exported to the EU (BBC, 2018d). If the customs duty cost and lead times due to international transportation increase due to Brexit, there is a possibility that the supply chain configuration will need to be changed; Toyota might close the UK factory and open one in the EU. Japanese electronics manufacturer Panasonic 
already moved its European main office from the UK to the EU in October 2018 because of concerns over taxation and incremental costs of exporting to the union (BBC, 2018b).

Furthermore, the UK is also exploring joining the Trans-Pacific Partnership (TPP) to secure the future of trade after Brexit by acquiring the Asian market which is expected to grow in the future (BBC, 2018c). The TPP is an FTA by 11 nations including Asian countries such as Japan, Singapore, and Malaysia (Ministry of Foreign Affairs of Japan, 2017). If the UK participates in the TPP, the total GDP within the TPP will increase by $3.2 \%$ and it will be a trade zone accounting for $16.2 \%$ of the world (IMF, 2018). Therefore, it will be an opportunity for Asian countries participating in the TPP to expand demand. Furthermore, when the UK joins the TPP, the customs duty of parts and products transported from Asian countries will be free, and it will be transported to the UK at a lower customs duty cost from the production bases in Asian countries. As an example of the impact of Brexit and the UK`s participation in the TPP, British electric manufacturer Dyson has selected Singapore instead of the UK for its new electric vehicle factory (FT, 2018). The opportunities to develop the UK market will increase, and the supply chain configuration of future Asian manufacturers may be affected. As in these examples, the customs duty rates may be dynamically changed by political and economic trading factors. As another example of a political factor, the US government has raised the customs duty rate on materials such as aluminum and steel in March 2018 (BBC, 2018e). Amin et al. (2017) stated that decisions of countries about customs duty rates may affect the sourcing decisions of companies in the global supply chain. Therefore, in future production, Asian manufacturers should consider and predict customs duty and economic trading factors such as Brexit and TPP simultaneously in order to structure sustainable supply chain network.

This study analyzes the impact of the change in the customs duty rate between the UK and EU caused by Brexit and the impact of changes in material import duties on the global supply chain network configuration. Among the triple bottom line of sustainable development, two aspects of economic and social responsibility such as customs duty and Brexit are considered. The supply chain network is modeled and extended based on previous studies (Urata et al. 2017, Nakamura et al. 2018) and formulated using mixed integer programming (Salvendy, 1982). Additionally, a bill of materials (BOM) of a product sample used for the experiments is prepared using 3D-CAD (Inoue et al. 2014) and an industry census. Next, by setting the case without Brexit as the baseline, a sensitivity analysis of the customs duty rate is conducted. After that, the influence of Brexit is discussed and cost evaluation is conducted for a scenario wherein the UK joins the TPP. Finally, material imported tax on the supply chain network configuration is examined, and the future Asian production scenario, when the UK leaves the EU and joins the TPP, is discussed.

\section{Literature Review}

In the literature on the sustainable supply chain, Blengini and Shields (2010) focused on the building materials supply chains and investigated the suitability, feasibility, appropriateness, effectiveness, 
completeness and redundancy of some of the most common sustainability reporting tools such as Sustainability Reporting (SR). Singh and Agrawal (2018) investigated the product placement strategy in the reverse supply chain and developed a framework to prioritize these strategies for effective reverse supply chain implementation using fuzzy TOPSIS approach. Mohanty (2018) modeled the enablers of integrated supply chain by incorporating sustainability, thereby aiming to construct its theory.

Table 1 shows a literature review of modeling global supply chain. In the literature on the global supply chain, Cohen et al. (1989) modeled the supply chain network design for a manufacturer using a basic framework that includes global factors such as tariffs, exchange rate, and taxes. Cohen and Lee (1989) developed a global supply chain model and evaluated manufacturing strategy. Their model considered taxes, tariffs, and transfer prices. Vidal and Goetschalckx (2001) developed a global supply chain model of an international company, which simultaneously selects a location of the facility that will maximize profit. Abdallah et al. (2012) modeled a supply chain that considers facility opening costs and conducted numerical experiments on carbon trading. Singh et al. (2018) used the fuzzy analytic hierarchy process methodology to compare four location alternatives and select the best one for the optimization of the global supply chain. Sáenz et al. (2018) described the transition between different supply chain structures as a way of coping with supply chain risk and introduced a risk management approach by an international company as an example. Karakawa and Kainuma (2013) designed a global closed-loop supply chain model that considered transfer price and after-tax income between two countries. Arntzen et al. (1995) quantitatively analyzed the cost-saving effect by restructuring the supply chain using multi-product BOM. Tsiakis et al. (2008) proposed a supply chain with a customs duty using mixed-integer linear programming and demonstrated the applicability of the approach.

González and Adenso-Díaz (2005) modeled how to determine the optimal end-of-life strategy for products using BOM in order to raise the concept of green product design and lifecycle. Johnson et al. (2013) proposed a methodology that predicts the cost of comprehensive manufacturing and distribution in both offshore and local production to analyze the sensitivity of the cost competitiveness of manufacturing sites. Danilovic and Vasiljevic (2014) defined a new optimization approach in the case of complex components in assembly systems and considered the management of component inventory levels in terms of timing and quantity under environmental uncertainty. Abbey and Guide $\operatorname{Jr}$ (2018) described a typology of remanufacturing based on direct observations across various remanufacturing industries on a closed-loop supply chain. The typology identified four distinct groupings based on the dimensions of a firm's strategic and product design focus. Miltenburg (2015) examined the influence of three changes in tariffs and FTAs on the facility network and strategy types of Michelin North America from 1950 to 2014. Kumar et al. (2015) developed a comprehensive classification method for green supply chain management (GSCM). The structural formula based on the GSCM classification methods allowed administrators to better understand the complex relationship between external and internal factors. Singh et al. (2018) proposed a design of offshore 
manufacturing contracts based on transfer pricing in the form of a two-stage planning problem that considered green tax. Khor and Hazen (2017) examined how consumer attitudes affected decisions to purchase recycled products using the purchase data of consumers in Malaysia and suggested that consumers are most likely to purchase energy-efficient offerings regardless of their original intentions. Hasani et al. (2015) proposed a model to optimize the closed-loop global supply chain profit of medical equipment considering uncertainty and developed an efficient memory algorithm.

Yoshizaki et al. (2016) proposed a method of selection another low-carbon supplier by estimating material-based greenhouse gases (GHG) including $\mathrm{CO} 2$ of each component using the LCI database combined with and Asian international Input-Output table. They analyzed the vacuum cleaner case procured from multiple countries among China, Japan and Malaysia. This method enabled us to reduce total GHG emissions within affordable cost increments by switching only some suppliers with lower GHG emissions. Urata et al. (2017) proposed a low-carbon design method of global supply chain network in Asia by using the same product example as well as Yoshizaki et al. (2016). The model minimizes the cost under targeted material-based $\mathrm{CO} 2$ emissions reduction rate and determines locations of suppliers and factories to satisfy the demand. The numerical experiment was conducted to analyze the effect on the cost and carbon emissions by changes in carbon tax prices. They demonstrated that the combination of low-carbon supplier's selection with the emission payments could achieve the $\mathrm{CO} 2$ emission target if higher carbon tax and target reduction rates were adopted. However, these studies did not consider global factors such as FTAs and EPAs.

In a literature review on tariff, FTA and EPA, Melo and Regolo (2014) evaluated the effects of the EPA between the East African Community (EAC) and the EU and discussed the benefits of simplifying the EAC-EU protocol on the rules of origin. Krueger (1997) analyzed the difference between the FTA and customs union that had not been discussed before. Hayakawa et al. (2017) analyzed the impact for exchange rates by the rules of origin on FTA using mathematical model. Brenton and Manchin (2003) argued that one of the factors underlying the difficulties in obtaining preferential access to the EU is the particularly the rules of origin. Ketterer et al. (2015) verified the impact of Japan's trade preferences on its multi-lateral tariff reductions using detailed product level data. Limão (2006) analyzed whether the preferential trade agreement (PTA) facilitates or slow down multilateral trade liberalization (MTL) using the U.S example. Cui et al. (2018) evaluated the impact of the FTAs between Japan, China, and South Korea on manufacturing industry. Dhingra et al. (2016) analyzed the impact of foreign direct investment (FDI) in the UK after Brexit. However, they did not model the supply chain network and analyze the impact of EPA and FTA on the supply chain network configuration.

In a literature review on global supply chain including actual FTAs as shown in table 1. Munson and Rosenblatt (1997) investigated the effect of global sourcing decisions under local content rules and argued that the importance of local content restrictions is increased by considering treaties such as NAFTA which is the North American FTA among the US, Canada and Mexico. Suppliers and final production sites are selected 
by the mixed integer programming to minimize the sum of purchasing, production, transportation, and fixed costs under no customs duty in the treaties. Amin et al. (2017) proposed a mathematical model for a closed-loop supply chain network by considering global factors such as the customs duties and exchange rates. The closed-loop supply chain model is a multi-objective mixed-integer linear programming model under uncertain demand, and applied to a network located in Canada. They analyzed the impact on the closed-loop supply chain network using sensitivity analysis of Canadian customs duty and exchange rates between US and Canadian dollars. Hosoda et al. (2016) modeled the global supply chain network with multiple FTAs such as TPP and NAFTA, and multiple rules for the customs duty including regional value content used in FTAs. Additionally, they showed some case studies of factory location selection under the assumption with applicable new tariff schemes such as TPP and NAFTA. Mariel and Minner (2017) modeled network designs under the North American Free Trade Agreement (NAFTA) local content requirement by applying non-linear mixed-integer program. The model introduced multiple benders cuts to improve the efficiency and applicability to real world planning problems. The numerical experiment showed the impact of local content requirements on the supply chain network design and compared various NAFTA options for calculating the local content of automotive supplies to each other. In the experiment, the customs duty rate between Mexico and the US was set at $25 \%$. Nakamura et al. (2018) modeled the global supply chain network with the customs duty and TPP/FTAs, and formulated with integer programming. They analyzed changes in supply chain network configuration by supplier selection among three countries of Japan, China, and Malaysia using sensitivity analysis for customs duty rate from $10 \%$ to $150 \%$ for parts and products. The results are discussed in terms of effects by TPP and customs duty rates using the model. However, they did not formulate expressing the material customs duty and analyze the impact of withdrawal of the EU customs union such as Brexit on the supply chain network configuration. 
Table 1 A literature review of modeling global supply chain

\begin{tabular}{|c|c|c|c|c|c|c|c|c|}
\hline & \multicolumn{4}{|c|}{ Global Supply Chain Management } & \multirow{2}{*}{$\begin{array}{c}\text { Material } \\
\text { BOM }\end{array}$} & \multicolumn{2}{|c|}{ Economic factor } & \multirow{2}{*}{ Method } \\
\hline Literature & $\begin{array}{l}\text { Supplier } \\
\text { selection }\end{array}$ & $\begin{array}{l}\text { Factory } \\
\text { location }\end{array}$ & $\begin{array}{c}\text { Production/ } \\
\text { shipment } \\
\text { quantities } \\
\end{array}$ & $\begin{array}{c}\text { Customs } \\
\text { duty }\end{array}$ & & FTA & Brexit & \\
\hline Cohen et al. (1989) & $\mathrm{O}$ & $\mathrm{O}$ & 0 & $\mathrm{O}$ & 0 & - & - & $\begin{array}{c}\text { Nonlinear mixed } \\
\text { integer programming }\end{array}$ \\
\hline Cohen and Lee (1989) & $\mathrm{O}$ & $\mathrm{O}$ & $\mathrm{O}$ & - & $\mathrm{O}$ & - & - & $\begin{array}{c}\text { Nonlinear mixed } \\
\text { integer programming }\end{array}$ \\
\hline Vidal and Goetschalckx (2001) & 0 & $\mathrm{O}$ & - & 0 & 0 & - & - & Linear programming \\
\hline Abdallah et al. (2012) & $\mathrm{O}$ & $\mathrm{O}$ & $\mathrm{O}$ & - & $\mathrm{O}$ & - & - & $\begin{array}{l}\text { Mixed integer } \\
\text { program }\end{array}$ \\
\hline Karakama and Kainuma (2013) & - & - & - & $\mathrm{O}$ & - & - & - & Linear programming \\
\hline Arntzen et al. (1995) & $\mathrm{O}$ & $\mathrm{O}$ & - & 0 & $\mathrm{O}$ & - & - & $\begin{array}{c}\text { Mixed integer } \\
\text { program }\end{array}$ \\
\hline Tsiakis et al.(2008) & $\mathrm{O}$ & $\mathrm{O}$ & 0 & 0 & - & - & - & $\begin{array}{l}\text { Mixed integer linear } \\
\text { programming }\end{array}$ \\
\hline Urata et al. (2017) & 0 & $\mathrm{O}$ & - & - & $\mathrm{O}$ & - & - & $\begin{array}{c}\text { Mixed integer } \\
\text { program }\end{array}$ \\
\hline Munson and Rosenblatt (1997) & 0 & $\mathrm{O}$ & 0 & - & $\mathrm{O}$ & NAFTA & - & $\begin{array}{l}\text { Mixed integer } \\
\text { program }\end{array}$ \\
\hline Amin et al. (2017) & $\mathrm{O}$ & $\mathrm{O}$ & $\mathrm{O}$ & $\mathrm{O}$ & - & NAFTA & - & $\begin{array}{c}\text { Mixed integer } \\
\text { linear programming }\end{array}$ \\
\hline Hosoda et al. (2016) & 0 & 0 & - & 0 & - & $\begin{array}{c}\text { NAFTA, } \\
\text { MERCO } \\
\text { SUR-Me } \\
\text { xico, } \\
\text { AJCEP, } \\
\text { and TPP }\end{array}$ & - & $\begin{array}{l}\text { Mixed integer } \\
\text { programming }\end{array}$ \\
\hline Mariel and Minner(2017) & $\mathrm{O}$ & $\mathrm{O}$ & $\mathrm{O}$ & $\mathrm{O}$ & $\mathrm{O}$ & NAFTA & - & $\begin{array}{c}\text { Nonlinear mixed } \\
\text { integer programming }\end{array}$ \\
\hline Nakamura et al. (2018) & 0 & $\mathrm{O}$ & $\mathrm{O}$ & 0 & $\mathrm{O}$ & TPP & - & $\begin{array}{l}\text { Mixed integer } \\
\text { program }\end{array}$ \\
\hline This study & 0 & $\mathrm{O}$ & 0 & 0 & $\mathrm{O}$ & TPP & $\mathrm{O}$ & $\begin{array}{l}\text { Mixed integer } \\
\text { program }\end{array}$ \\
\hline
\end{tabular}




\section{Modeling and Formulation}

\section{Notation and Assumptions}

This section explains the modeling approach to analyze the effects of Brexit and TPP on the global supply chain of Asian manufacturers. Urata et al. (2017) modeled a global supply chain network evaluating supplier and factory selection, and formulated total costs including transportation cost, procurement cost of parts, and factory opening costs. However, their model cannot analyze the effect of Brexit because it did not consider the customs duty. Nakamura et al. (2018) modeled a global supply chain network with customs duty based on Urata et al. (2017). However, their model did not express the material customs duty. Therefore, our study models the global supply chain network with material customs duty based on Urata et al. (2017) and Nakamura et al. (2018) as shown in Figure 1. The model has sets of suppliers $L$, factories $F$ and markets $M A$. First, supplier $l$ produces part $j$. Then, the part $j$ is transported from supplier $l$ to factory $a$. Each product consisting of $n_{j}$ parts is assembled at factory $a$, and then, these products are transported to market $b$ as finished products.

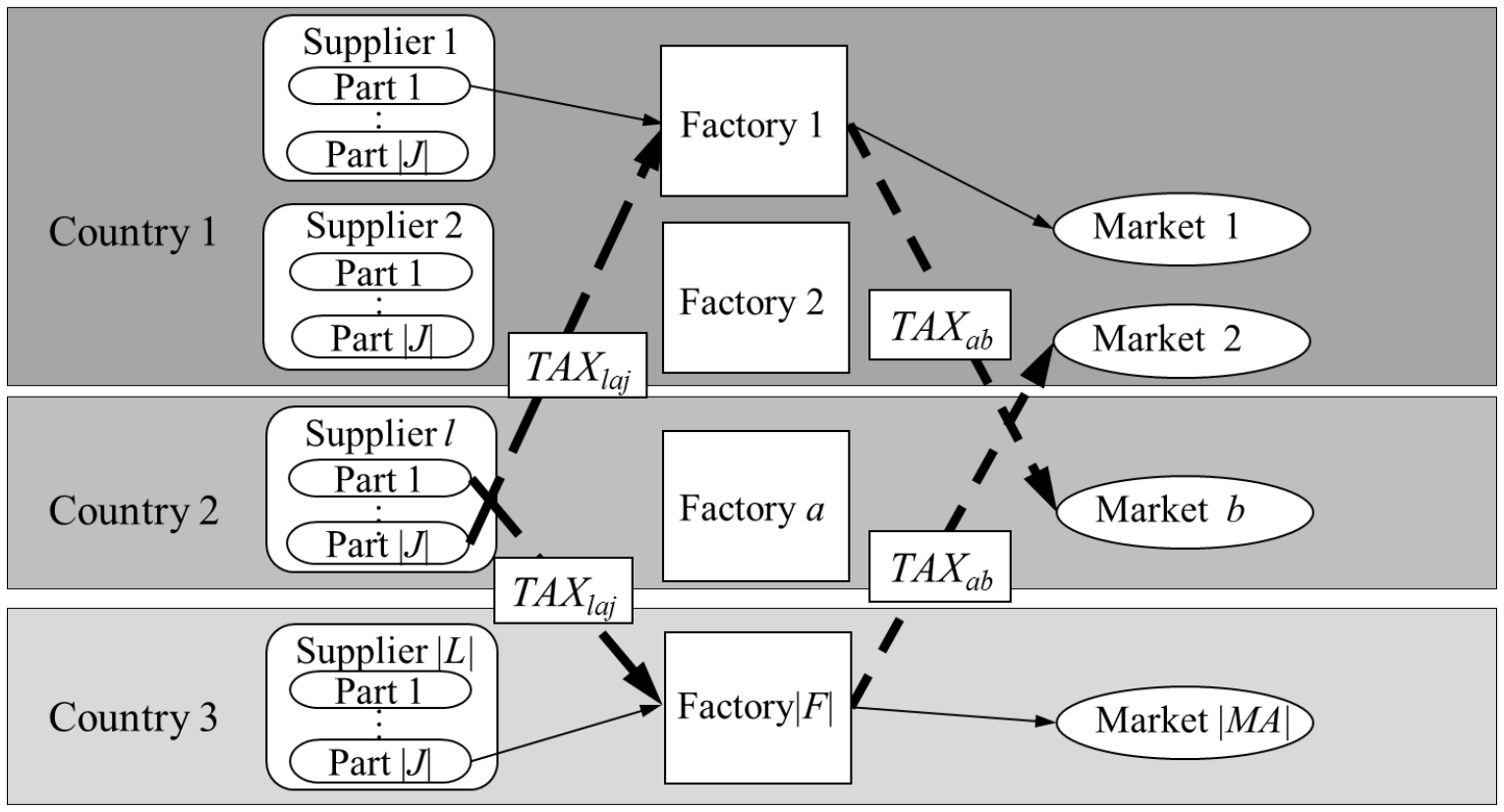

Figure 1 Model of global supply chain network with customs duty

When parts $j$ and products are transported, minimum order quantities are represented by $Q_{\text {min,laj }}$ and $Q_{\text {min, } a b}$, respectively. The production capacity of factory $a$ is represented by $Q_{\max , a}$. To evaluate the customs duty rate of the material type $m$, the customs duty cost of part $T A X_{l a j}$ is applied when part $j$ made from the material $m$ is transported from supplier $l$ to factory $a$ beyond the FTAs. On the other hand, the customs duty cost of the product $T A X_{a b}$ is applied when the products are transported from factory $a$ to market $b$ beyond the FTAs. 
Notations used in this study are as follows:

i) Sets

$L \quad$ Set of suppliers, $l \in L$

$F \quad$ Set of factories, $a \in F$

MA Set of markets, $b \in M A$

$J \quad$ Set of parts, $j \in J$

$M \quad$ Set of materials of parts $j, m \in M_{j}$

ii) Decision variables

$f_{l a j} \quad$ Number of parts $j$ transported from supplier $l$ to factory $a$

$f_{a b} \quad$ Number of product transportation from factory $a$ to market $b$

$z_{a b} \quad 1$, if the route between factory $a$ and market $b$ is opened

0 , otherwise

$u_{a} \quad 1$, if the fixed opening cost at factory $a$ is opened

0 , otherwise

iii) Production parameters

$n_{j} \quad$ Number of parts $j$ needed for a product

$S_{l j} \quad 1$, if supplier $l$ supplies part $j$

0 , otherwise

V Very large number

$N_{\text {product }, b} \quad$ Number of product units demanded in market $b$

$Q_{\text {min, } l a j} \quad$ Minimum order quantity from supplier $l$ and factory $a$ for part $j$

$Q_{\text {min, }, a b} \quad$ Minimum order quantity from factory $a$ to market $b$ for product

$Q_{\max , a} \quad$ Production capacity at factory $a$

iv) Cost parameters

$L C_{l a} \quad$ Transportation cost of parts from supplier $l$ to factory $a$

$L C_{a b} \quad$ Transportation cost of product from factory $a$ to market $b$

$P C_{l j} \quad$ Procurement cost of part $j$ supplied from supplier $l$

$M C_{a} \quad$ Manufacturing cost of product at factory $a$

$O C_{a b} \quad$ The fixed opening route cost between factory $a$ and market $b$

$F C_{a} \quad$ The fixed factory opening cost of factory $a$

$d_{l a} \quad$ The distance between supplier $l$ and factory $a$

$d_{a b} \quad$ The distance between factory $a$ and market $b$ 
$\alpha_{j} \quad$ Cost coefficient of parts transportation

$\alpha_{p} \quad$ Cost coefficient of product transportation

v) Tax parameters

$T A X_{l a j} \quad$ Customs duty cost per unit on transportation of parts $j$ from supplier $l$ to factory $a$

$T A X_{a b} \quad$ Customs duty cost per unit on transportation from factory $a$ to market $b$

$\delta(l, a, m) \quad$ Customs duty rate on the material $m$ of the parts $j$ transported from supplier $l$ to factory $a$

$\delta(a, b) \quad$ Customs duty rate on the products transported from factory $a$ to market $b$

\section{Objective Function}

In this model, the objective function is the minimization of the total cost including transportation, procurement, customs duty, fixed opening routes, and factory costs in Eq. (1).

Objective function:

$$
\sum_{l \in L} \sum_{a \in F} \sum_{j \in J}\left(L C_{l a}+P C_{l j}+T A X_{l a j}\right) f_{l a j}+\sum_{a \in F} \sum_{b \in M A}\left(L C_{a b}+M C_{a}+T A X_{a b}\right) f_{a b}+\sum_{a \in F} \sum_{b \in M A} O C_{a b} z_{a b}+\sum_{a \in F} F C_{a} u_{a} \rightarrow \min
$$

where

$$
L C_{l a}=d_{l a} \times \alpha_{j}
$$

$L C_{a b}=d_{a b} \times \alpha_{p}$

$T A X_{l a j}=P C_{l j} \times \delta(l, a, m) \quad \forall m \in M_{j}$

and $T A X_{a b}=M C_{a} \times \delta(a, b)$.

Constraints:

$\sum_{a \in F} f_{a b}=\quad N_{\text {product }, b} \quad \forall b \in M A$

$\sum_{l \in L} S_{l j} f_{l a j}=\sum_{b \in M A} f_{a b} \times n_{j} \quad \forall a \in F, \forall j \in J$

$f_{a b} \leq V z_{a b} \quad \forall a \in F, \forall b \in M A$

$\sum_{b \in M A} f_{a b} \leq Q_{\max , a} u_{a} \quad \forall a \in F$

$f_{l a j}, f_{a b} \geq 0 \quad \forall l \in L, \forall a \in F, \forall b \in M A, \forall j \in J$

$z_{a b}, u_{a}=\{1,0\} \quad \forall a \in F, \forall b \in M A$ 


$$
\begin{array}{ll}
f_{l a j} \geq Q_{\min , l a j} & \forall l \in L, \forall a \in F, \forall j \in J \\
f_{a b} \geq Q_{\text {min }, a b} & \forall a \in F, \forall b \in M A
\end{array}
$$

Eq. (2) implies that the unit transportation cost $L C_{l a}$ is obtained by multiplying the distance $d_{l a}$ between supplier $l$ and factory $a$ with the cost coefficient of parts transportation $\alpha_{j}$. Eq. (3) indicates that the unit transportation cost $L C_{a b}$ is obtained by multiplying the distance $d_{a b}$ between factory $a$ and market $b$ by the cost coefficient of product transportation $\alpha_{p}$ as well as Eq. (2). The unit customs duty cost $T A X_{\text {laj }}$ of the part is obtained by multiplying the procurement $\operatorname{cost} P C_{l j}$ of the part $j$ supplied from supplier $l$ by the tax rate on the material $m$ of part $j$ transported from supplier $l$ to factory $a$, as shown in Eq. (4). The unit customs duty $T A X_{a b}$ of the product is also obtained by multiplying the manufacturing cost of product at factory $a$ by the tax rate on the product transportation from factory $a$ to market $b$ as shown in Eq. (5).

Regarding constraints, Eq. (6) shows that the opened factory satisfies the demand of each market. Eq. (7) represents the condition that the assigned suppliers satisfy the demand for all parts. Eq. (8) indicates that the products are transported only through the opening route. Eq. (9) represents that all products are produced only at the opened factory $a$ within production capacity $Q_{\max , a}$. Eqs. (10) and (11) set the non-negativity and binary restrictions. Eqs. (12) and (13) respectively indicate that the transported parts $f_{l a j}$ and products $f_{a b}$ are equal to or above the minimum order quantity $Q_{\text {min,laj }}$ from supplier $l$ to the factory $a$ for part $j$ and $Q_{\text {min,ab }}$ from the factory $a$ to market $b$.

\section{Example of Calculation Procedure for Transportation Cost}

This section illustrates a calculation procedure for transportation cost using an example. According to respective Eqs. (2) and (3), the transportation cost of parts from supplier \#1 in Fukuoka to factory \#2 in France, $L C_{l, 2}$, is calculated, and after that, the transportation cost of products from factory $\# 2$ in France to market $\# 3$ in Poland, $L C_{2,3}$, is also calculated as follows:

$$
\begin{aligned}
L C_{1,2} & =d_{1,2} \times \alpha_{j} \\
& =9329.2[\mathrm{~km}] \times 0.00001[\mathrm{US} \$ / \mathrm{km}]=0.093292[\mathrm{US} \$] \\
L C_{2,3} & =d_{2,3} \times \alpha_{p} \\
& =1225.4[\mathrm{~km}] \times 0.0001[\mathrm{US} \$ \mathrm{~km}]=0.12254[\mathrm{US} \$]
\end{aligned}
$$

\section{Example Problem}

In order to illustrate the effect of the model, this section prepares an example problem where an Asian manufacturer produces vacuum cleaners. The vacuum cleaners are assembled using 22 parts based on a BOM similar to that used by Yoshizaki et al. (2016). This BOM is made from the 3D-CAD model (Inoue et al. 2014), which is used to measure the weight of each part to be used in calculating their individual procurement 
costs. The reason for using the BOM is to analyze cases that the customs duty for a specific material such as aluminum and steel has been increased. In the numerical experiment, the supply chain network configuration is obtained by solving for the mixed integer programing problem with Eqs. (1) - (13).

The assumptions of the example problem such as location and customs duty with Brexit are set as follows:

- Similar to the actual global supply chain problem with Brexit, this study sets candidate factories in the United Kingdom, France, and Poland like the actual factories Toyota (Toyota, 2018).

- The candidate cities for the demand of final assembled products are London, Paris, and Warsaw, and a total of 2,000 units are transported to the markets from the factories.

- The locations of the suppliers are cities in Japan based on Urata et al. (2017) in Appendix A.

- Minimum order quantities for the parts and products are zero such that $Q_{\min , l a j}$ and $Q_{\min , a b}=0$.

- Production capacity at factory $a$ is 3,000 units as $Q_{\max , a}=3,000$.

- Cost coefficient of parts and product transportation are set as the same as Urate et al. (2017) such that $\alpha_{j}$ $=0.00001[\mathrm{US} \$ \mathrm{~km}]$ and $\alpha_{p}=0.0001[\mathrm{US} \$ / \mathrm{km}]$.

- When the parts and products are transported internationally, the customs duty is applied with rates for parts $\delta(l, a, m)$ and products $\delta(a, b)$. In addition, for mutual international transportation within EU, this study sets that the customs duty rates become zero.

- In the case with Brexit, for mutual international transportations between the UK and EU, the customs duty of the product is applied.

- The distance between supplier $l$ and factory $a, d_{l a}$, and the distance between factory $a$ and market $b, d_{a b}$, are estimated by Google Maps with direct distances.

- The customs duty rates are not changed within the production planning period, and there is only one product model with a long life cycle and stable demand. This is because it is assumed that manufacturers use such assumptions for a long-term perspective on decisions involving supply chain selection and factory location.

- Fluctuations in exchange rates are not considered in this study because it focuses on analyzing the impact of Brexit and customs duty rate on supply chains.

\section{Assumptions of Baseline Example}

The assumptions of baseline example such as customs duty are set in the case without Brexit as follows:

- Numerical experiment as a baseline is conducted in the case without Brexit.

- The customs duty rate of product is $10 \%$.

- In the case without Brexit, the customs duty of the product becomes $0 \$$ for mutual international transportations between the UK and EU. 


\section{Results: Effect of Brexit}

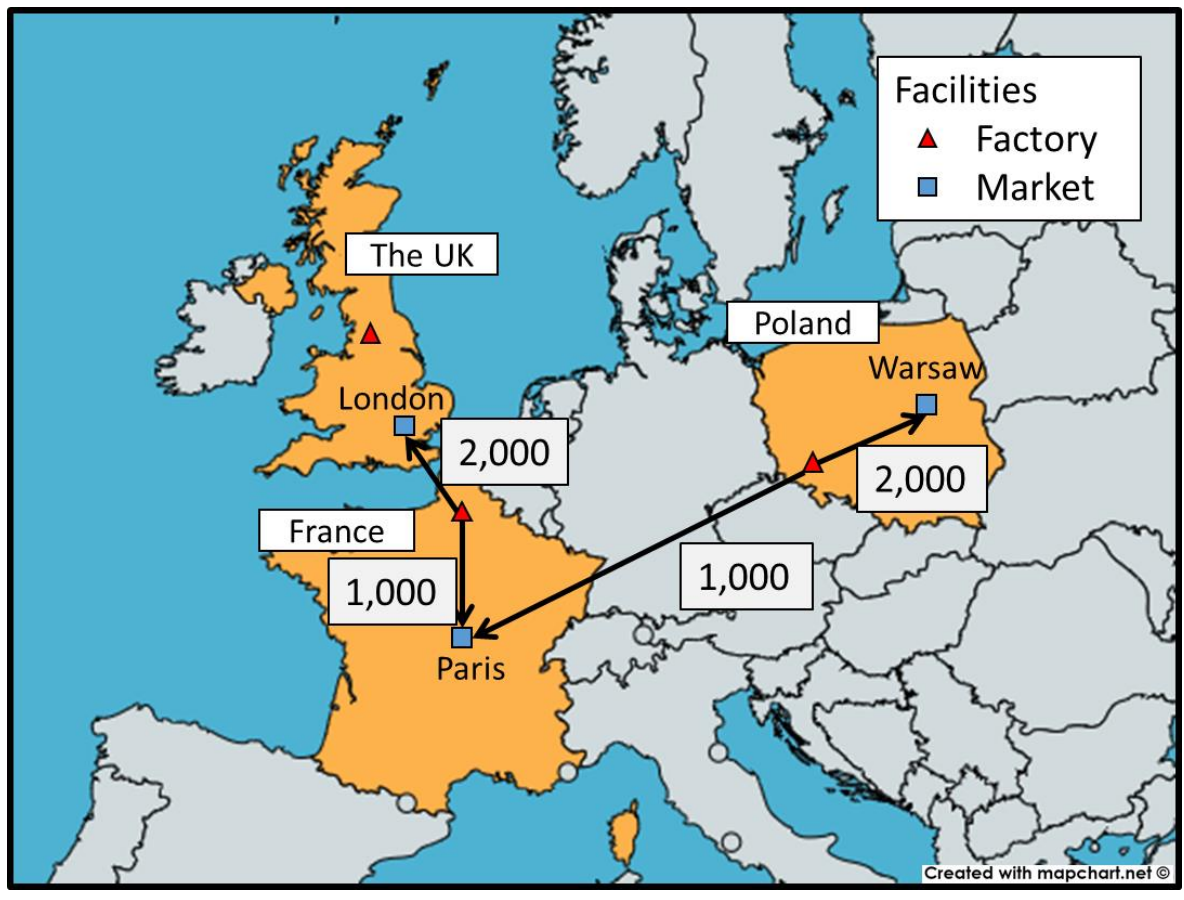

Figure 2 Optimal network configurations when the customs duty rate of the product is $5 \%$ in the case with Brexit (Baseline) (Map source: https://mapchart.net/)

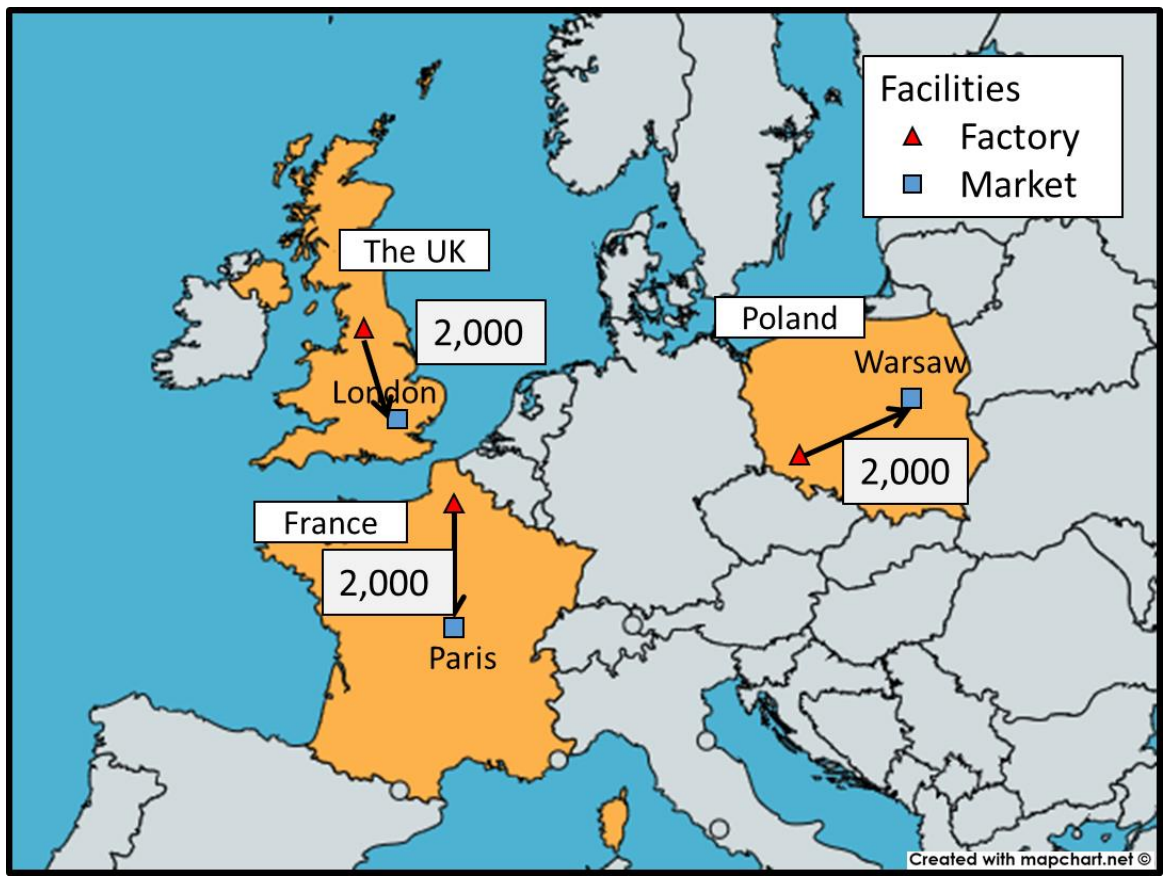

Figure 3 Optimal network configurations when the customs duty rate of the product is $10 \%$ in the case with Brexit (Map source: https://mapchart.net/) 
Table 2 Total cost and its breakdown when product customs duty rates are 5\% and 10\% with Brexit [US\$]

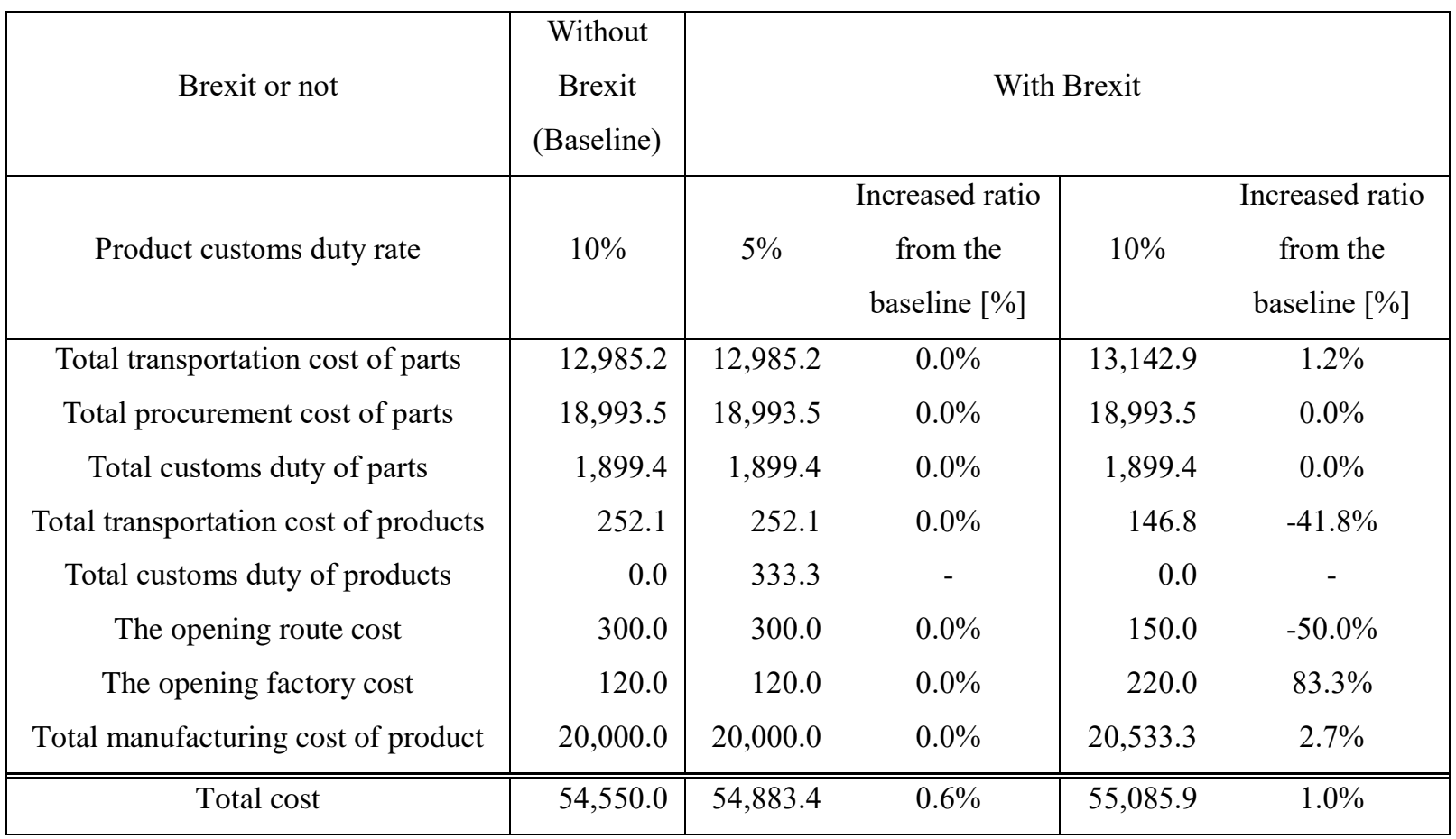

Table 3 Total cost and its breakdown by each supply chain configuration with Brexit [US\$]

\begin{tabular}{|c|c|c|c|}
\hline Brexit or not & \multicolumn{2}{|r|}{ With Brexit } & \multirow{4}{*}{ Difference[\%] } \\
\hline & $\begin{array}{l}\text { Manufacturer does } \\
\text { not change the } \\
\text { configuration }\end{array}$ & $\begin{array}{l}\text { Result of cost optimal } \\
\text { configuration }\end{array}$ & \\
\hline Product customs duty rate & $10 \%$ & $10 \%$ & \\
\hline Supply chain configuration pattern & Across country & Domestic & \\
\hline Total transportation cost of parts & $12,985.2$ & $13,142.9$ & $-1.2 \%$ \\
\hline Total procurement cost of parts & $18,993.5$ & $18,993.5$ & $0.0 \%$ \\
\hline Total customs duty of parts & $1,899.4$ & $1,899.4$ & $0.0 \%$ \\
\hline Total transportation cost of products & 252.1 & 146.8 & $41.8 \%$ \\
\hline Total customs duty of products & 666.7 & 0.0 & - \\
\hline The opening route cost & 300.0 & 150.0 & $50.0 \%$ \\
\hline The opening factory cost & 120.0 & 220.0 & $-83.3 \%$ \\
\hline Total manufacturing cost of product & $20,000.0$ & $20,533.3$ & $-2.7 \%$ \\
\hline Total cost & $55,216.8$ & $55,085.9$ & $0.2 \%$ \\
\hline
\end{tabular}


To analyze the supply chain configuration as affected by the change in the product customs duty rate with Brexit, this section conducts an experiment and a sensitivity analysis using the customs duty rate. In this experiment, the customs duty rate of the part is set at $10 \%$. As of 2018 , the customs duty rate of a vacuum cleaner is from $1.7 \%$ to $2.2 \%$ when the products are exported from outside the EU to the UK, France, and Poland (World Tariff, 2018). The case without Brexit is set as the baseline where the customs duty rate of the product is $10 \%$. With Brexit, the customs duty rate of the product is set at $5 \%$ and $10 \%$ for mutual international transportation between the UK and EU.

\section{Baseline}

Figure 2 shows optimal network configurations when the customs duty rate of product is set at $10 \%$ without Brexit. The factories are opened in both France and Poland. A total of 3,000 units of the products are produced in a Polish factory; 2,000 units are transported to markets in Poland, and 1,000 to markets in France. Additionally, another 3,000 units of the products are produced in a French factory; 1,000 units are transported to markets in France, and 2,000 to markets in the UK. Table 2 shows total cost and its breakdown when the customs duty rate of product is set at $10 \%$ without Brexit. From table 2, total customs duty cost of products becomes $0 \$$. This is because all products on the supply chain are transported within the EU where the customs duty of parts and product are free.

\section{A 5\% Customs Duty with Brexit}

Figures 2 and 3 show optimal network configurations when the customs duty rate of the product is set at 5\% and $10 \%$ with Brexit. It is observed in figure 2 that this network configuration is the same as the baseline without Brexit. Similar to the results of baseline, the factories are opened in both France and Poland. However, the UK factory was not opened because its manufacturing cost is $8 \%$ higher than that of the France and Poland factories. Moreover, only two factories in France and Poland were enough to satisfy all the demand including that from the UK. Therefore, these two factories will keep the company from opening a factory in the UK.

Table 2 shows the total cost and its breakdown when the product customs duty rates are $5 \%$ and $10 \%$ with Brexit. When the customs duty rate of the product is $5 \%$, the total cost increases by $0.6 \%$ from the baseline without Brexit. This is because the supply chain network configuration did not change from the baseline without Brexit, but the customs duty cost increases for the products transported to the UK from EU.

\section{A $10 \%$ Customs Duty with Brexit}

Figure 3 shows the optimal network configurations when the customs duty rate of the product is $10 \%$ with Brexit. When the customs duty rate of product is $10 \%$ with Brexit, the supply chain network configuration is different from the baseline without Brexit. It is found that the three factories were opened, the products were 
produced in each factory and were transported within their domestic markets only. One of the reasons for this setup is to avoid the customs duty of the products transported to the UK with Brexit. Another reason is to decrease the total transportation cost of the products because the transportation cost to the domestic market tends to be lower than to the foreign markets because of the shorter distances.

As shown in table 2 , when the customs duty rate of the product is $10 \%$, the total cost increases by $1 \%$ from the baseline without Brexit. The total transportation cost of the products, however, becomes $41.8 \%$ less than in the baseline without Brexit. This is because transportation from all factories to the markets is switched to the EU domestic market only to avoid the customs duty on the products shipped to the UK from EU. Meanwhile, the procurement cost of parts and the customs duty on them are not changed from the baseline without Brexit. This is because the selected suppliers did not change in the supply chain configuration.

As the above discussions, it is quantitatively shown that there is a case wherein the domestic demand in the UK is satisfied with the products produced in the factory inside the UK. This is even though the customs duty rate is increased by only $10 \%$ with Brexit. Furthermore, this experiment also shows that Brexit can affect not only the UK but also the whole supply chain network configuration within EU.

Next, the total cost is calculated for such a case to compare it with the case where the supply chain configuration is not changed from the baseline without Brexit. Table 3 shows the total cost and its breakdown by each supply chain configuration with Brexit when the customs duty rate of product is $10 \%$. This result shows that if the manufacturer does not change the supply chain configuration across the countries when the customs duty rate of product is $10 \%$, total cost increases by $0.2 \%$ compared with changing to the optimal domestic supply chain configuration. This is because the total customs duty of the products increases to 666.7 [US\$], though the factory opening cost is decreased. It is noted that the known customs duty cost of the products increases as the duty rate increases by more than $10 \%$. Therefore, if the switching cost for reconfiguring the supply chain is higher than the total cost increment of $0.2 \%$, the supply chain configuration should be changed to the optimal one using domestic transportation.

The proposed model in this study analyzed and illustrated the influence of fluctuations in the customs duty rate caused by Brexit on the global supply chain configuration. From the viewpoint of future production of Asian manufacturers with production bases within the EU, these experimental results indicate that it is necessary to restructure a domestic supply chain configuration if the customs duty rate increased because of Brexit. Actually, British electronic product manufacturer Dyson selected Singapore instead of the UK for its new electric car factory (FT, 2018).

\section{Results: Effect of the UK's participation in TPP}

The UK is exploring joining the TPP in an effort to secure the future of its trade after Brexit (BBC, 2018c). This section conducts a sensitivity analysis to analyze the changes in the supply chain configuration when the UK leaves the EU and joins the TPP. In this experiment, the customs duty rate of the material part is set at 
$10 \%$. The other assumptions used in this scenario are the same as those in the previous experiments. An additional scenario for the material customs duty rate increase is prepared here, where the customs duty rates are zero when the parts are transported to the UK from Japan, a TPP member.

Table 4 shows the total cost and its breakdown when the UK leaves the EU and joins the TPP. Compared to the baseline without Brexit, the total cost decreased by $0.2 \%$ and the customs duty of the parts decreased by $33.3 \%$ when the UK leaves the EU and joins TPP. This is because the UK factory was opened because of Brexit, and the customs duty rate of the parts from Japan to the UK became free with the UK's participation in the TPP. On the other hand, each cost except the customs duty on the parts was not changed in the case where the UK leaves the EU but does not join the TPP. This is because the supply chain configuration result will be the same as shown in figure 3 .

Table 4 Total cost and its breakdown when the UK leaves the EU and joins the TPP [US\$]

\begin{tabular}{|c|c|c|c|c|c|}
\hline \multirow[b]{2}{*}{ Scenario } & \multirow{2}{*}{$\begin{array}{l}\text { Without } \\
\text { Brexit } \\
\text { The UK } \\
\text { does not } \\
\text { leave the } \\
\text { EU } \\
\text { (Baseline) }\end{array}$} & \multicolumn{4}{|c|}{ With Brexit } \\
\hline & & \multicolumn{2}{|c|}{$\begin{array}{c}\text { The UK does not join } \\
\text { the TPP }\end{array}$} & \multicolumn{2}{|c|}{ The UK joins the TPP } \\
\hline Product customs duty rate & $10 \%$ & $10 \%$ & $\begin{array}{c}\text { Increased } \\
\text { ratio from } \\
\text { the } \\
\text { baseline } \\
{[\%]}\end{array}$ & $10 \%$ & $\begin{array}{l}\text { Increased } \\
\text { ratio from } \\
\text { the baseline } \\
{[\%]}\end{array}$ \\
\hline Total transportation cost of parts & $12,985.2$ & $13,142.9$ & $1.2 \%$ & $13,142.9$ & $1.2 \%$ \\
\hline Total procurement cost of parts & $18,993.5$ & $18,993.5$ & $0.0 \%$ & $18,993.5$ & $0.0 \%$ \\
\hline Total customs duty of parts & $1,899.4$ & $1,899.4$ & $0.0 \%$ & $1,266.2$ & $-33.3 \%$ \\
\hline Total transportation cost of products & 252.1 & 146.8 & $-41.8 \%$ & 146.8 & $-41.8 \%$ \\
\hline Total customs duty of products & 0.0 & 0.0 & - & 0.0 & - \\
\hline The opening route cost & 300.0 & 150.0 & $-50.0 \%$ & 150.0 & $-50.0 \%$ \\
\hline The opening factory cost & 120.0 & 220.0 & $83.3 \%$ & 220.0 & $83.3 \%$ \\
\hline Total manufacturing cost of product & $20,000.0$ & $20,533.3$ & $2.7 \%$ & $20,533.3$ & $2.7 \%$ \\
\hline Total cost & $54,550.0$ & $55,085.9$ & $1.0 \%$ & $54,452.7$ & $-0.2 \%$ \\
\hline
\end{tabular}


The experiment results after Brexit in the previous section showed only cases where the total cost increased from the baseline without Brexit. However, it was shown that there is a case where the total cost decreased from the baseline without Brexit, that is, when the UK leaves the EU and joins the TPP. Therefore, the UK government would likely participate in the TPP.

Based on this result, Asian manufacturers with production bases in Europe have the opportunity to reduce total costs, while maintaining their factories in the UK, if the UK leaves the EU and joins the TPP.

\section{Results: Effect of Material Customs Duty Rate Increase}

In addition to Brexit, the customs duty for materials may change due to political reasons. In March 2018, the US government raised the customs duty rate on materials such as aluminum and steel (BBC, 2018e). To analyze the impact on total cost and supply chain configuration when the customs duty rate of the material in the UK increases, a sensitivity analysis of the customs duty rate of the material is also conducted using the proposed model.

Table 5 Total cost and its breakdown: Sensitivity analysis of the customs duty rate of material parts [US\$]

\begin{tabular}{|c|r|r|r|}
\cline { 1 - 2 } Customs duty rate of product & \multicolumn{1}{|c|}{$10 \%$} & \multicolumn{1}{c}{$10 \%$} & \multirow{2}{*}{ Difference [\%] } \\
\cline { 1 - 3 } Customs duty rate of parts made of aluminum in the UK & $10 \%$ & $20 \%$ & \\
\hline Total transportation cost of parts & $13,142.9$ & $13,142.9$ & $0.0 \%$ \\
Total procurement cost of parts & $18,993.5$ & $18,993.5$ & $0.0 \%$ \\
Total customs duty of parts & $1,899.4$ & $1,969.9$ & $3.7 \%$ \\
Total transportation cost of products & 146.8 & 146.8 & $0.0 \%$ \\
Total customs duty of products & 0.0 & 0.0 & - \\
The opening route cost & 150.0 & 150.0 & $0.0 \%$ \\
The opening factory cost & 220.0 & 220.0 & $0.0 \%$ \\
Total manufacturing cost of product & $20,533.3$ & $20,533.3$ & $0.0 \%$ \\
\hline \hline Total cost & $55,085.9$ & $55,156.4$ & $0.1 \%$ \\
\hline \hline
\end{tabular}

An additional scenario for the increased material customs duty rate is prepared here, where the customs duty rate is $20 \%$ when the aluminum parts are transported to the UK from Japan. The other assumptions used in this scenario are the same as those in the previous experiments.

Table 5 shows the total cost and its breakdown when the customs duty rate of the parts made of aluminum increases. Compared to when the customs duty rate of aluminum is $10 \%$, the total cost increases by $0.1 \%$ and the customs duty on the parts increases by $3.7 \%$ when the customs duty rate of aluminum is at $20 \%$. 
Meanwhile, when the customs duty rate of the product is $5 \%$, the total cost does not change. This is because the UK factory was not selected in the optimal network configurations, which were affected by increasing the customs duty rate of the aluminum parts. Therefore, the total cost is not affected by increasing the import customs duty of aluminum parts going to the UK when the customs duty rate of the product is $5 \%$.

From the viewpoint of future production of Asian manufacturers with production bases within the EU, these experiment results indicate that it is not necessary to restructure the supply chain configuration even though the customs duty rate of some materials increased because of Brexit as in this case.

\section{Conclusion and Future Studies}

This study modeled the material-based global supply chain network and analyzed the impact of changes in the UK customs duty rate of products caused by Brexit on the global supply chain network configuration. It also conducted a sensitivity analysis of the customs duty rate of the product. A summary of the results follows:

- Effect of Brexit and evaluation of the proposed model

In the sensitivity analysis of the customs duty rate of product with Brexit, there were two cases observed to reduce the custom duty costs. One case is the supply chain configuration using the customs union of the EU. The other one is a domestic supply chain that transported products from each factory to the domestic market in each country. Therefore, if the customs duty rate increases by Brexit, manufacturer will be necessary to restructure supply chain configuration by locating the domestic factory and market.

- Effect of the UK's participation in the TPP

When the UK leaves the EU and joins the TPP, there was a case where the total cost in the global supply chain network decreased compared to the baseline without Brexit. Therefore, it is reasonable for the UK to join the TPP.

- Effect of Material Customs Duty Rate Increase

In the sensitivity analysis of the customs duty rate for the material, it was shown that even if the customs duty rate for aluminum products was increased by $10 \%$, there was a case where the optimal cost configuration is not changed although the total cost increased. Therefore, the impact of a change in the customs duty rate of the materials on the supply chain configuration is smaller than the effect of Brexit in this case.

- From the above results and summary, it is illustrated that the proposed model enables us to evaluate the impact of Brexit on the global supply chain and its reconfiguration. 
Increasingly, global supply chains have become extended, inter-connected and complex. A slight change in trade agreement will have a huge impact on the present and future supply chain configuration as well as the investment decisions. Capabilities to model the impact of movements in costs, labor availability, trade restrictions and impact on environment are vital to Asian manufacturers. Hence, the ability to test scenarios to inform supply chain decisions will be critical.

This study quantitatively evaluated what there are opportunities or risks of increasing costs associated with the selection of a sustainable supply chain configuration for Asian manufacturers brought on by the political and economic factors of each country such as Brexit and participation in the TPP. The study also shows how new trading rules from non-partner countries can critically disrupt existing global supply chain equilibrium (i.e., the supply chain structure, positioning of inventory, and logistics operations). Asian manufacturers may evaluate a move for more local sourcing or opening new facilities and setting up warehouses for finished goods or raw materials in different trading areas to overcome any barriers to the movement of goods.

However, this study uses a simple model with several limitations, such as a single type of product, a fixed demand quantity, and only one Japanese supplier. Furthermore, this model did not consider other EPAs and FTAs.

- Multiple types of products are not considered in this study. However, the supply chain configuration may change by considering multiple products. This is because the customs duty rate of the products is different for each product type. Therefore, future work can be expanded to cover a multiple supply chain model with multiple types of product.

- This study conducted experiments with a fixed demand quantity, and the proposed model did not consider volume discount arising from fluctuations in demand quantity. Therefore, this study did not analyze the impact of changes in demand and volume discount caused by Brexit on the supply chain configuration. However, fluctuations in demand quantity caused by Brexit may affect the supply chain. As such, the models should be expanded to take into account volume discounts.

- The models assume that all the suppliers are in Japan. However, this assumption is not always true in the actual case as there are cases where parts are procured from other countries. Our model can be used to conduct numerical experiments in cases where the manufacturer procures parts from multiple suppliers. Therefore, sensitivity analysis considering supplier selection from several Asian TPP members, such as Vietnam and Malaysia, may be an interesting investigation to verify the future production in Asia. 
- Currently, the Japan-EU EPA has been concluded, and the Regional Comprehensive Economic Partnership (RCEP) is being discussed in Asia. RCEP is a wide-area FTA in which 16 countries including Japan, China, Korea, India, Australia, and New Zealand participate in the Association of Southeast Asian Nations (Ministry of Foreign Affairs of Japan, 2017). These FTAs will greatly impact future Asian production. Therefore, it is a future work to analyze other FTAs, especially considering RCEP which is closely related to production in Asia.

- The proposed supply chain model did not consider the exchange rates and did not analyze their fluctuation as caused by Brexit. Therefore, future studies should expand the model to include exchange rates and analyze their fluctuations as a result of Brexit.

- This study considered two aspects of economic and social responsibility among the triple bottom line of sustainable development. However, environmental performance for global warming is not evaluated in this study. However, this study already treated material-based supply chain network, therefore, future studies can analyze and evaluate the environmental performance of the supply chain network using data on materials and parts with $\mathrm{CO} 2$ emission.

\section{Acknowledgement}

This research was partially supported by the Japan Society for the Promotion of Science (JSPS), Invitational Fellowships for Research in Japan (Long-term), L18560, and KAKENHI, Grant-in-Aid for Scientific Research (A), JP18H03824, from 2018 to 2019.

\section{References}

AO Dos Santos, M., Svensson, G., \& Padin, C. (2014), "A "fivefold bottom line" approach of implementing and reporting corporate efforts in sustainable business practices", Management of Environmental Quality: An International Journal, Vol. 25 No. 4, pp. 421-430.

Abbey, J.D. and V. D. R. Guide, Jr. (2018), “A typology of remanufacturing in closed-loop supply chains", International Journal of Production Research, Vol. 56 No. 1-2, pp.374-384.

Abdallah, T., Farhat, A., Diabat, A. and Kennedy, S. (2012), "Green supply chain with carbon trading and environmental sourcing: Formulation and life cycle assessment”, Applied Mathematical Modeling, Vol. 36, pp. 4271-4285.

Amin, S. H. and Baki, F. (2017), "A facility location model for global closed-loop supply chain network design”, Applied Mathematical Modeling, Vol. 41, pp. 316-330.

Arntzen, B. C., Brown, G. G., Harrison, T. P. and Trafton, L. L. (1995), "Global supply chain management at 
digital equipment corporation", Interfaces, Vol. 25 No. 1, pp. 69-93.

BBC, (2018a), "Brexit: What do the words all mean?!", available at: http://www.bbc.co.uk/newsround/38637145 (Accessed on Oct 31, 2018).

BBC, (2018b), "Panasonic to move Europe headquarters from UK to Amsterdam", available at: https://www.bbc.com/news/business-45351288 (Accessed on Oct 30, 2018)

BBC, (2018c), “TPP: Could UK really join Pacific trade group?", available at: https://www.bbc.com/news/business-42549541 (Accessed on Oct 17, 2018)

BBC, (2018d), "Toyota says no-deal Brexit would stall production at Burnaston", available at: https://www.bbc.com/news/business-45676633 (Accessed on Oct 30, 2018)

BBC, (2018e), "US steel and aluminum imports face big tariffs, Trump says", available at: http://www.bbc.com/news/world-us-canada-43249614 (Accessed on May 31, 2018)

Blengini, G. A., \& Shields, D. J. (2010), "Green labels and sustainability reporting: Overview of the building products supply chain in Italy", Management of Environmental Quality: An International Journal, Vol. 21 No. 4, pp. 477-493.

Brenton, P. and Manchin, M. (2003), "Making EU trade agreements work: the role of rules of origin", World Economy, Vol. 26 No. 5, pp. 755-769.

Cohen, M. A. and Lee, H. L. (1989), "Resource development analysis of global manufacturing \& distribution network", Journal of Manufacturing and Operations Management, Vol. 2, pp. 81-104.

Cohen, M. A., Fisher, M. and Jaikumar, R. (1989), "International manufacturing and distribution networks: a normative model framework", Managing international manufacturing, Vol. 13, pp. 67-93.

Cui, L., Song, M. and Zhu, L. (2018), "Economic evaluation of the trilateral FTA among China, Japan, and South Korea with big data analytics", Computers \& Industrial Engineering, (in press).

Danilovic, M. and Vasiljevic, D. (2014), "A novel relational approach for assembly system supply planning under environmental uncertainty", International Journal of Production Research, Vol. 52 No. 13, pp. 4007-4025.

De Melo, J. and Regolo, J. (2014), "The African Economic Partnership Agreements with the EU: Reflections inspired by the case of the East African Community", Journal of African Trade, Vol. 1, pp. 15-24.

Dhingra, S., Ottaviano, G., Sampson, T. and Van Reenen, J. (2016), “The impact of Brexit on foreign investment in the UK." BREXIT 2016, pp. 24-33.

Eskandarpour, M., Dejax, P., Miemczyk, J., and Péton, O. (2015). "Sustainable supply chain network design: an optimization-oriented review", Omega, Vol. 54, pp. 11-32.

Financial Times (2018), "Dyson Chooses Singapore for First Electric Car Plant" https://www.ft.com/content/2695b8b0-d60b-11e8-ab8e-6be0dcf18713 (Accessed on 4 Nov 2018)

González, B. and Adenso-Díaz, B. (2014), "A bill of materials-based approach for end-of-life decision making in design for the environment”, International Journal of Production Research, Vol. 43 No. 10, pp. 2071-2099. 
Hasani, A., Zegordi, S. H. and Nikbakhsh, E. (2015), "Robust closed-loop global supply chain network design under uncertainty the case of the medical device industry", International Journal of Production Research, Vol. 53 No. 5, pp. 1596-1624.

Hayakawa, K., Kim, H. S. and Yoshimi, T. (2017), "Exchange rate and utilization of free trade agreements: Focus on rules of origin", Journal of International Money and Finance, Vol. 75, pp. 93-108.

Her Majesty's Government, (2018), "THE FUTURE RELATIONSHIP BETWEEN THE UNITED KINGDOM AND THE EUROPEAN UNION" https://assets.publishing.service.gov.uk/government/uploads/system/uploads/attachment_data/file/725288/The _future_relationship_between_the_United_Kingdom_and_the_European_Union.pdf (Accessed on 9 Nov 2018)

Hosoda, J., Funaki, K. and Chida, T. (2016), "Recent issues in international supply chain network designeconomic partnership modeling”, In Fujisawa K., Shinano Y. and Waki H (Eds.), Optimization in the Real World, Vol. 13, pp. 139-155.

IMF, (2018), "World Economic Outlook Databases", https://www.imf.org/en/Publications/SPROLLS/world-economic-outlook-databases (Accessed on Oct 28, 2018)

Inoue, M., Yamada, T. and Ishikawa, H. (2014), "Life cycle design support system based on 3D-CAD for satisficing product performances and reduction of environmental loads at the early phase of design", Design Engineering, Vol. 49 No. 10, pp. 543-549 (in Japanese).

Johnson, M. D., Sawaya, W. J. and Natarajarathinam, M. (2013), "A methodology for modelling comprehensive international procurement costs", International Journal of Production Research, Vol. 51, No. 18, pp. 5549-5564.

Karakawa, T. and Kainuma, Y. (2013), "Design of a Global Closed-Loop Supply Chain Model”, Journal of Japan Industrial Management Association, Vol. 64 No. 2E, pp. 366-375.

Ketterer, T. D., Bernhofen, D.M. and Milner, C., (2015), "The impact of trade preferences on multilateral tariff cuts: Evidence for Japan”, Journal of The Japanese and International Economies, Vol. 38, pp. 31-51.

Khor, K.S. and Hazen, B.T. (2017), "Remanufactured products purchase intentions and behavior: Evidence from Malaysia”, International Journal of Production Research, Vol. 55 No. 8, pp. 2149-2162.

Krueger, A. O. (1997), "Free trade agreements versus customs unions", Journal of Development Economics, Vol. 54 No. 1, pp. 169-187.

Kumar, V., Holt, D., Ghobadian, A. and Garza-Reyes, J.A. (2015), "Developing green supply chain management taxonomy-based decision support system", International Journal of Production Research, Vol. 53 No. 21, pp. 6372-6389.

Limão, N. (2006), "Preferential trade agreements as stumbling blocks for multilateral trade liberalization: Evidence for the United States", American Economic Review, Vol. 96 No. 3, pp. 896-914. 
Mahler, D. (2007). “The sustainable supply chain”, Supply Chain Management Review, Vol. 11 No. 8, pp. 59-60.

Mariel, K. and Minner, S. (2017), "Benders decomposition for a strategic network design problem under NAFTA local content requirements", Omega, Vol. 68, pp. 62-75.

Miltenburg, J. (2015), "Changes in manufacturing facility-, network-, and strategy-types at the Michelin North America Company from 1950 to 2014", International Journal of Production Research, Vol. 53 No. 10, pp. 3175-3191.

Ministry of Foreign Affairs of Japan, (2017), "Agreement at the Ministerial level on the TPP Negotiations among 11 countries", https://www.mofa.go.jp/press/release/press4e_001788.html (Accessed on Oct 30, 2018)

Ministry of Foreign Affairs of Japan, (2018), "Free Trade Agreement (FTA) and Economic Partnership Agreement (EPA)", http://www.mofa.go.jp/policy/economy/fta/index.html (Accessed on May 24, 2018).

Ministry of Foreign Affairs of Japan, (2018), "Regional Comprehensive Economic Partnership (RCEP)", https://www.mofa.go.jp/policy/economy/page2e_000001.html (Accessed on Oct 28, 2018).

Mohanty, M. (2018), “Assessing sustainable supply chain enablers using total interpretive structural modeling approach and fuzzy-MICMAC analysis", Management of Environmental Quality: An International Journal, Vol. 29 No. 2, pp. 216-239.

Munson, C. L. and Rosenblatt, M. J. (1997), "The impact of local content rules on global souring decisions", Production and Operations Management, Vol. 6 No. 3, pp. 277-289.

Nakamura, K., Ijuin, H., Yamada, T., Ishigaki, A. and Inoue, M. (2018), "Modeling of global supply chain network with Trans-Pacific Partnership", Journal of the Society of Plant Engineers Japan, Vol. 30 No. 3, pp. 69-81 (in Japanese).

Pearson education, (2018), “LDOCE - Longman Dictionary”, https://www.ldoceonline.com/jp/ (Accessed on Dec 11, 2018).

Salvendy, G. (1982), Handbook of Industrial Engineering, CA: John Wiley and Sons Inc.

Singh, R. K., \& Agrawal, S. (2018), “Analyzing disposition strategies in reverse supply chains: fuzzy TOPSIS approach", Management of Environmental Quality: An International Journal, Vol. 29 No.3, pp. 427-443.

Singh, R.K., Chaudhary, N. and Saxena, N. (2018), "Selection of warehouse location for a global supply chain: A case study", IIMB Management Review, (in press).

Singh, S., Haldar, N. and Bhattacharya, A. (2018), "Offshore manufacturing contract design based on transfer price considering green tax: a bilevel programming approach", International Journal of Production Research, Vol. 56 No. 5, pp. 1825-1849.

Song, M., Fisher, R., Wang, J. L., and Cui, L. B. (2018b), "Environmental performance evaluation with big data: Theories and methods", Annals of Operations Research, Vol. 270 No. 1-2, pp. 459-472.

Song, M., Du, J., and Tan, K. H. (2018a), "Impact of fiscal decentralization on green total factor productivity", International Journal of Production Economics, Vol. 205, pp. 359-367. 
Sáenz, M. J., Revilla, E. and Acero, B. (2018), "Aligning supply chain design for boosting resilience”, Business Horizons, Vol. 61, pp. 443-452.

Toyota, (2018), Worldwide Operations, https://newsroom.toyota.co.jp/en/detail/5286101 (Accessed on May 24, 2018).

Tsiakis, P. and Papageorgiou, L. G. (2008), "Optimal production allocation and distribution supply chain networks", International Journal of Production Economics, Vol. 111 No. 2, pp. 468-483.

Urata, T., Yamada, T., Itsubo, N. and Inoue, M. (2017), "Global supply chain network design and Asian analysis with material-based carbon emissions and tax”, Computers \& Industrial Engineering, Vol. 113, pp. 779-792.

Vidal, C. J. and Goetschalckx, M. A. (2001), "Global supply chain model with transfer pricing and transportation cost allocation”, European Journal of Operational Research, Vol. 129, pp. 134-158.

World tariff online database, (2018), https://ftn.fedex.com/wtonline/jsp/navframe.jsp?pageName=wtoMain.jsp\&current=Search\%20Options (Accessed on Oct 8, 2018)

Yoshizaki, Y., Yamada, T., Itsubo, N. and Inoue, M. (2016), "Material Based Low-Carbon and Economic Supplier Selection with Estimation of GHG Emissions and Affordable Cost Increment for Parts Production among Multiple Asian Countries”, Japan Industrial Management Association, Vol. 66 No. 4E, pp. 435-442. 
Appendix A Data Table

Table A1 Bill of materials for procurement costs in the case of a vacuum cleaner (Yoshizaki et al. 2016).

\begin{tabular}{|c|c|c|c|c|c|c|c|}
\hline $\begin{array}{l}\text { Part } \\
\text { No. }\end{array}$ & Part name & $\begin{array}{c}\text { Material } \\
\text { No. }\end{array}$ & Material name & $\begin{array}{l}\text { Japanese } \\
\text { suppliers }\end{array}$ & $\begin{array}{l}\text { Number } \\
\text { of parts }\end{array}$ & $\begin{array}{c}\text { Weight } \\
\text { [g] }\end{array}$ & $\begin{array}{c}\text { Procurement } \\
\text { cost in Japan } \\
\text { [US\$] }\end{array}$ \\
\hline 1 & Wheel of nozzle & 1 & Polypropylene & Fukuoka & 2 & 7.07 & 0.0196 \\
\hline 2 & Wheel stopper & 1 & Polypropylene & Hiroshima & 2 & 1.71 & 0.0047 \\
\hline 3 & Upper nozzle & 1 & Polypropylene & Yokohama & 1 & 50.35 & 0.0698 \\
\hline 4 & Lower nozzle & 1 & Polypropylene & Osaka & 1 & 41.25 & 0.0572 \\
\hline 5 & Nozzle & 1 & Polypropylene & Nagoya & 1 & 34.50 & 0.0478 \\
\hline 6 & Right handle & 1 & Polypropylene & Sapporo & 1 & 48.93 & 0.0678 \\
\hline 7 & Switch & 2 & Polyvinyl chloride & Kumamoto & 1 & 4.65 & 0.0058 \\
\hline 8 & Left handle & 1 & Polypropylene & Kobe & 1 & 51.70 & 0.0716 \\
\hline 9 & Left body & 1 & Polypropylene & Shizuoka & 1 & 187.27 & 0.2595 \\
\hline 10 & Right body & 1 & Polypropylene & Kyoto & 1 & 179.88 & 0.2493 \\
\hline 11 & Dust case cover & 3 & Methacrylate resin & Sendai & 1 & 36.57 & 0.0964 \\
\hline 12 & Mesh filter & 4 & Carbon fiber & Niigata & 1 & 18.45 & 0.5990 \\
\hline 13 & Connection pipe & 5 & Aluminum alloy & Wakayama & 1 & 47.17 & 0.1012 \\
\hline 14 & Dust case & 6 & Methacrylate resin & Hiroshima & 1 & 175.69 & 0.4632 \\
\hline 15 & Exhaust tube & 2 & Polyvinyl chloride & Kumamoto & 1 & 32.04 & 0.0401 \\
\hline 16 & Upper filter & 4 & Carbon fiber & Niigata & 1 & 17.74 & 0.5759 \\
\hline 17 & Lower filter & 1 & Polypropylene & Wakayama & 1 & 29.33 & 0.0406 \\
\hline 18 & Protection cap & 7 & $\begin{array}{l}\text { Polystyrene } \\
\text { (ABS) }\end{array}$ & Kobe & 1 & 22.29 & 0.0437 \\
\hline 20 & $\begin{array}{c}\text { Rubber of outer } \\
\text { flame of fan }\end{array}$ & 8 & Synthetic rubber & Sapporo & 1 & 22.85 & 0.0556 \\
\hline 21 & $\begin{array}{l}\text { Outer flame of } \\
\text { fan }\end{array}$ & 1 & Polypropylene & Sendai & 1 & 55.11 & 0.1182 \\
\hline 22 & Lower fan & 1 & Polypropylene & Yokohama & 1 & 15.08 & 0.0209 \\
\hline 23 & Fan & 5 & Aluminum alloy & Nagoya & 1 & 62.10 & 0.1332 \\
\hline \multicolumn{5}{|c|}{ Total } & 24 & 1141.73 & 3.14 \\
\hline \multicolumn{5}{|c|}{ Average } & 1.09 & 51.90 & 0.14 \\
\hline \multicolumn{5}{|c|}{ Standard deviation } & 0.29 & 55.14 & 0.17 \\
\hline
\end{tabular}


Table A2 The fixed opening route cost between factory $a$ and market $b$ : $O C_{a b}$ [US\$]

\begin{tabular}{|c|c|c|c|c|c|}
\hline & & & \multicolumn{3}{|c|}{ Market $b$} \\
\hline & \multirow{2}{*}{\multicolumn{2}{|c|}{ Location }} & $\# 1$ & $\# 2$ & $\# 3$ \\
\hline & & & The UK & France & Poland \\
\hline \multirow{3}{*}{ Factory $a$} & $\# 1$ & The UK & 50 & 100 & 150 \\
\hline & $\# 2$ & France & 100 & 50 & 100 \\
\hline & $\# 3$ & Poland & 150 & 100 & 50 \\
\hline
\end{tabular}

Table A3 The fixed factory opening cost at factory $a$ : $F C_{a}$ [US\$]

\begin{tabular}{|c|c|c|c|}
\cline { 2 - 4 } \multicolumn{1}{c|}{} & \multicolumn{2}{|c|}{ Location } & Cost \\
\hline \multirow{4}{*}{ Factory $a$} & $\# 1$ & The UK & 100 \\
\cline { 2 - 4 } & $\# 2$ & France & 70 \\
\cline { 2 - 4 } & $\# 3$ & Poland & 50 \\
\hline
\end{tabular}

Table A4 Manufacturing cost of product at factory $a$ : $M C_{a}$ [US\$]

\begin{tabular}{|c|c|c|c|}
\cline { 2 - 4 } \multicolumn{1}{c|}{} & \multicolumn{2}{c|}{ Location } & Cost \\
\hline \multirow{3}{*}{ Factory $a$} & $\# 1$ & The UK & 3.6 \\
\cline { 2 - 4 } & $\# 2$ & France & 3.333333 \\
\cline { 2 - 4 } & $\# 3$ & Poland & 3.333333 \\
\hline
\end{tabular}


Table A5 Transportation cost of part from supplier $l$ to factory $a$ : $L C_{l a}$ [US\$]

\begin{tabular}{|c|c|c|c|c|c|}
\hline & & & \multicolumn{3}{|c|}{ Factory $a$} \\
\hline & \multirow{2}{*}{\multicolumn{2}{|c|}{ Location }} & $\# 1$ & $\# 2$ & \#3 \\
\hline & & & The UK & France & Poland \\
\hline \multirow{13}{*}{ Supplier $l$} & $\# 1$ & Fukuoka & 0.093485 & 0.093292 & 0.085738 \\
\hline & $\# 2$ & Hiroshima & 0.093534 & 0.09349 & 0.086138 \\
\hline & $\# 3$ & Yokohama & 0.095137 & 0.095549 & 0.088849 \\
\hline & $\# 4$ & Osaka & 0.09441 & 0.094554 & 0.087462 \\
\hline & $\# 5$ & Nagoya & 0.094436 & 0.094372 & 0.087732 \\
\hline & $\# 6$ & Sapporo & 0.087828 & 0.088583 & 0.082511 \\
\hline & \#7 & Kumamoto & 0.094396 & 0.094191 & 0.086613 \\
\hline & $\# 8$ & Kobe & 0.094297 & 0.094424 & 0.087306 \\
\hline & $\# 9$ & Shizuoka & 0.095179 & 0.095502 & 0.088666 \\
\hline & $\# 10$ & Kyoto & 0.094187 & 0.094359 & 0.087307 \\
\hline & \#11 & Sendai & 0.092633 & 0.093208 & 0.086788 \\
\hline & $\# 12$ & Niigata & 0.092388 & 0.092847 & 0.086247 \\
\hline & $\# 13$ & Wakayama & 0.094753 & 0.094862 & 0.087715 \\
\hline
\end{tabular}

Table A6 Transportation cost of product from factory $a$ to market $b$ : $L C_{a b}$ [US\$]

\begin{tabular}{|c|c|c|c|c|c|}
\hline & & & \multicolumn{3}{|c|}{ Market $b$} \\
\hline & \multirow{2}{*}{\multicolumn{2}{|c|}{ Location }} & $\# 1$ & $\# 2$ & \#3 \\
\hline & & & The UK & France & Poland \\
\hline \multirow{3}{*}{ Factory $a$} & $\# 1$ & The UK & 0.01808 & 0.05247 & 0.15235 \\
\hline & $\# 2$ & France & 0.02908 & 0.01921 & 0.12254 \\
\hline & $\# 3$ & Poland & 0.1149 & 0.1025 & 0.03609 \\
\hline
\end{tabular}

